\title{
Hemoglobin Subunit Beta
}

National Cancer Institute

\section{Source}

National Cancer Institute. Hemoglobin Subunit Beta. NCI Thesaurus. Code C84983.

Hemoglobin subunit beta (147 aa, $\sim 16 \mathrm{kDa}$ ) is encoded by the human HBB gene. This protein plays a role in the transport of oxygen to tissues of the adult body. 